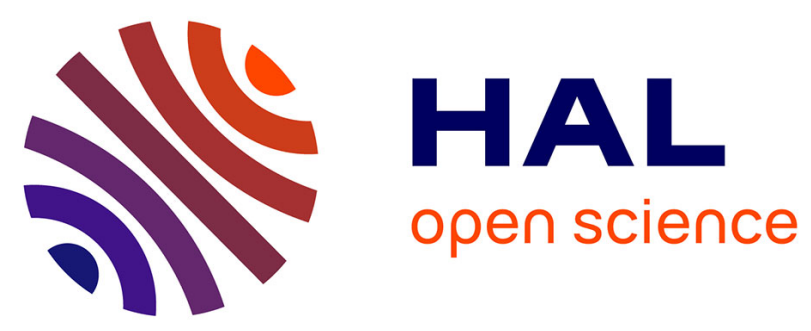

\title{
Exacerbated in vivo metabolic changes suggestive of a spontaneous muscular vaso-occlusive crisis in exercising muscle of a sickle cell mouse
}

\author{
Benjamin Chatel, Laurent Messonnier, David Bendahan
}

\section{To cite this version:}

Benjamin Chatel, Laurent Messonnier, David Bendahan. Exacerbated in vivo metabolic changes suggestive of a spontaneous muscular vaso-occlusive crisis in exercising muscle of a sickle cell mouse. Blood Cells, Molecules and Diseases, 2017, 65, pp.56-59. 10.1016/j.bcmd.2017.05.006 . hal-01657970

\author{
HAL Id: hal-01657970 \\ https://hal.science/hal-01657970
}

Submitted on 18 May 2018

HAL is a multi-disciplinary open access archive for the deposit and dissemination of scientific research documents, whether they are published or not. The documents may come from teaching and research institutions in France or abroad, or from public or private research centers.
L'archive ouverte pluridisciplinaire HAL, est destinée au dépôt et à la diffusion de documents scientifiques de niveau recherche, publiés ou non, émanant des établissements d'enseignement et de recherche français ou étrangers, des laboratoires publics ou privés. 


\section{Accepted Manuscript}

Exacerbated in vivo metabolic changes suggestive of a spontaneous muscular vaso-occlusive crisis in exercising muscle of a sickle cell mouse

Benjamin Chatel, Laurent A. Messonnier, David Bendahan

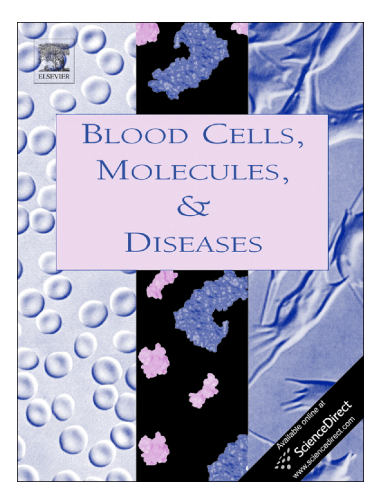

PII: S1079-9796(17)30119-5

DOI: doi: 10.1016/j.bcmd.2017.05.006

Reference: YBCMD 2192

To appear in: Blood Cells, Molecules and Diseases

Received date: 10 March 2017

Revised date: 10 May 2017

Accepted date: 10 May 2017

Please cite this article as: Benjamin Chatel, Laurent A. Messonnier, David Bendahan , Exacerbated in vivo metabolic changes suggestive of a spontaneous muscular vasoocclusive crisis in exercising muscle of a sickle cell mouse, Blood Cells, Molecules and Diseases (2017), doi: 10.1016/j.bcmd.2017.05.006

This is a PDF file of an unedited manuscript that has been accepted for publication. As a service to our customers we are providing this early version of the manuscript. The manuscript will undergo copyediting, typesetting, and review of the resulting proof before it is published in its final form. Please note that during the production process errors may be discovered which could affect the content, and all legal disclaimers that apply to the journal pertain. 


\title{
Exacerbated in vivo metabolic changes suggestive of a spontaneous muscular vaso-occlusive crisis in exercising muscle of a sickle cell mouse
}

Benjamin Chatel $^{\mathrm{a}}$, Laurent A. Messonnier, ${ }^{\mathrm{a}, \mathrm{b}}$, David Bendahan ${ }^{\mathrm{a}}$

\begin{abstract}
${ }^{a}$ Aix-Marseille Univ, CNRS, CRMBM, Marseille, France Chambéry, France

\section{Correspondence}

Benjamin CHATEL

Centre de Résonance Magnétique Biologique et Médicale

Faculté de Médecine, 27 Boulevard Jean Moulin

13385 Marseille Cedex 05

benjamin.chatel@live.fr
\end{abstract}

'Université Savoie Mont Blanc, Laboratoire Interuniversitaire de Biologie de la Motricité,

Running title

Muscular vaso-occlusive crisis in a sickle mouse 


\section{Abbreviations}

${ }^{31} \mathrm{P}-\mathrm{MRS}$ : Magnetic resonance spectroscopy of phosphorus 31

$\mathrm{HbS}$ : sickle hemoglobin

HIE: high intensity exercise

M1: the animal suspected to develop a VOC

MIE: moderate intensity exercise

$\mathrm{P}_{\mathrm{i}}$ : inorganic phosphate

PCr: phosphocreatine

RBC: red blood cell

SCD: sickle cell disease

VOC: vaso-occlusive crisis 


\begin{abstract}
While sickle cell disease (SCD) is characterized by frequent vaso-occlusive crisis (VOC), no direct observation of such an event in skeletal muscle has been performed in vivo. The present study reported exacerbated in vivo metabolic changes suggestive of a spontaneous muscular VOC in exercising muscle of a sickle cell mouse. Using magnetic resonance spectroscopy of phosphorus 31, phosphocreatine and inorganic phosphate concentrations and intramuscular $\mathrm{pH}$ were measured throughout two standardized protocols of rest exercise - recovery at two different intensities in ten SCD mice. Among these mice, one single mouse presented divergent responses. A statistical analysis (based on confidence intervals) revealed that this single mouse presented slower phosphocreatine resynthesis and inorganic phosphate disappearance during the post-stimulation recovery of one of the protocols, what could suggest an ischemia. This study described, for the first time in a sickle cell mouse in vivo, exacerbated metabolic changes triggered by an exercise session that would be suggestive of a live observation of a muscular VOC. However, no evidence of a direct cause-effect relationship between exercise and VOC has been put forth.
\end{abstract}

\title{
Key words
}

Physical activity, red blood cell sickling, HbS polymerization, magnetic resonance spectroscopy of phosphorus 31 . 


\section{Introduction}

Sickle cell disease (SCD) is a genetic hemoglobinopathy related to the production of abnormal hemoglobin ( $\mathrm{HbS}$ ). In its deoxygenated form, $\mathrm{HbS}$ tends to polymerize, leading to the sickling of red blood cells (RBC) [1]. Owing to their poor deformability and elevated adhesion, sickle RBCs tend to obstruct the microcirculation thereby leading to vaso-occlusive crises (VOC) that represent the most severe clinical complications of SCD [2]. If this type of crisis has been acknowledged in many tissues [2], the potential occurrence of such an event in skeletal muscle has rarely been documented $[3 ; 4 ; 5 ; 6]$. To the best of our knowledge, no direct observation of a skeletal muscle VOC has been performed in real time.

In a previous study aiming at evaluating the impacts of $\mathrm{HbS}$ on skeletal muscle metabolism [7], we submitted control and SCD mice to standardized rest - stimulation recovery protocols. We used magnetic resonance spectroscopy of phosphorus $31\left({ }^{31} \mathrm{P}-\mathrm{MRS}\right)$ in order to assess changes in phosphocreatine $(\mathrm{PCr})$ and inorganic phosphate $\left(\mathrm{P}_{\mathrm{i}}\right)$ concentrations as well as intramuscular $\mathrm{pH}$ throughout two different exercise protocols. In this study, we have reported a more pronounced intramuscular exercise-induced acidosis in SCD mice as compared to their control counterparts [7]. During these investigations, one mouse displayed drastically divergent deviations from the metabolic profile we recorded for the other SCD mice during the moderate intensity protocol.

Among the observed particularities, the rates of $\mathrm{PCr}$ resynthesis and $\mathrm{P}_{\mathrm{i}}$ disappearance during the post-exercise recovery were much slower than normal. Given the wellacknowledged relationship between ischemia and post-exercise PCr resynthesis [8], we hypothesized that the metabolic events we recorded for this mouse was evidencing an acute ischemic episode suggestive of a VOC. In this note, we intended to report a detailed statistical analysis of the metabolic changes occurring during this protocol in order to illustrate that this event could suggest a muscular VOC. This single preclinical case could be of interest given the very few evidence of the occurrence of VOC in skeletal muscle.

\section{Materials and Methods}

\section{Animals}

All animal experiments were approved by the Institutional Animal Care Committee of Aix-Marseille University (permit number: 01835.02). Ten 5 month-old SCD mice (males, Townes model of SCD [9]) were investigated as previously described [7]. Mice were tested twice over a one-week period in order to assess muscle energetics in response to two stimulation protocols with two different intensities i.e. MIE (moderate intensity exercise) and HIE (high-intensity exercise), performed 48 hours apart in a random order. The animal suspected to develop a VOC (called M1) initially performed the HIE and then the MIE.

Anesthetized animal were placed supine within a home-built cradle especially designed for a strictly non-invasive investigation of posterior hindlimb muscle energetics during electrical stimulation [7]. Investigations were performed using a 47/30 Biospec Avance MR system (Bruker, Karlsruhe, Germany) equipped with a 120-mm BGA12SL (200 mT/m) gradient insert. ${ }^{31} \mathrm{P}$ spectra (8-kHz sweep width; 2,048 data points) from the posterior hindlimb muscle region were acquired continuously throughout the standardized experimental protocol consisting in $4.7 \mathrm{~min}$ of rest, $6 \mathrm{~min}$ of electrical stimulation, and $16 \mathrm{~min}$ of post-stimulation recovery. MRS data acquisition was gated to muscle stimulation with the aim of reducing potential motion artifacts due to contraction. ${ }^{31} \mathrm{P}$-MRS data were processed using a proprietary software developed using IDL (Interactive Data Language, Research System, Inc., Boulder, CO, USA) [10]. For each spectrum, the relative concentrations of [PCr] and inorganic phosphate $\left[\mathrm{P}_{\mathrm{i}}\right.$ ] were calculated [11]. Intracellular pH was calculated from the chemical shift of the $\mathrm{P}_{\mathrm{i}}$ signal relative to $\mathrm{PCr}$ [12].

One week after the in vivo protocol, mice were anesthetized intraperitoneally with a Ketamine $(110 \mathrm{~mL} / \mathrm{kg})$ - Xylazine $(10 \mathrm{~mL} / \mathrm{kg})$ mixture and the gastrocnemius muscle was 
harvested, frozen in liquid nitrogen and then stored at $-80^{\circ} \mathrm{C}$. The whole gastrocnemius muscle of M1 and 6 animals of the SCD group were crushed and used for enzyme activity analyses. Approximately $30 \mathrm{mg}$ of muscle was homogenized in $500 \mu \mathrm{L}$ of buffer $\left(\mathrm{NaH}_{2} \mathrm{PO}_{4}\right.$ $200 \mathrm{mM}, \mathrm{Na}_{2} \mathrm{HPO}_{4} 200 \mathrm{mM}$, Magnesium acetate $4 \mathrm{mM}$, Aprotinine $10 \mu \mathrm{g} / \mathrm{mL}$, EGTA $1 \mathrm{mM}$ ) with a tissue homogenizer (Polytron PT 1200 E, Kinematica, Switzerland). After $0.1 \%$ triton was added, samples were incubated 45 minutes at $4^{\circ} \mathrm{C}$ and then centrifuged $(1 \mathrm{~h}, 10000 \mathrm{~g}$, $\left.4^{\circ} \mathrm{C}\right)$. The supernatant was cautiously collected and enabled enzymatic analysis after protein concentration was assayed with BSA as a standard (Pierce BCA Protein Assay Kit, Thermo Scientific). Myokinase (MK), creatine kinase (CK), hexokinase (HEX), enolase (ENO), lactate dehydrogenase (LDH) and citrate synthase (CS) maximal activities (Ul/mg of protein) were determined by absorbance with a multilabel microplate reader (Chameleon, Hidex, Finland) as previously described [13].

Considering that we observed the peculiar metabolic changes in a single mouse only (M1), we determined a 95\% confidence interval for the remaining 9 mice in the group and compared the results of $\mathrm{M} 1$ with respect to the confidence intervals computed for each metabolic variable. 


\section{Results and discussion}

Figure 1 illustrates the metabolic profiles recorded in M1 and the remaining SCD group (mean $\pm \mathrm{SD}$ and the $95 \%$ confidence interval) during the MIE. While the initial $[\mathrm{PCr}]$ and $\left[\mathrm{P}_{\mathrm{i}}\right]$ changes during stimulation were not abnormal for $\mathrm{M} 1$ (figures $1 \mathrm{~A}$ and $1 \mathrm{~B}$, respectively), the corresponding changes quantified for the second half of the stimulation period were significantly different. Indeed, a larger PCr consumption was measured for M1 as compared to its counterparts (figure $1 \mathrm{~A}, \mathrm{p}<0.05$ ). $\left[\mathrm{P}_{\mathrm{i}}\right]$ increased almost linearly in $\mathrm{M} 1$ up to exercise completion whereas it rapidly plateaued in the SCD group, although the corresponding values for M1 remained within the confidence interval defined in the SCD group. During the recovery period, both $[\mathrm{PCr}]$ and $\left[\mathrm{P}_{\mathrm{i}}\right]$ returned towards their resting values. However, for $\mathrm{M} 1$, the $\mathrm{PCr}$ recovery and $\mathrm{P}_{\mathrm{i}}$ disappearance rates were much slower as compared to the SCD group (figure 1). Interestingly, both $\mathrm{PCr}$ and $\mathrm{P}_{\mathrm{i}}$ concentrations were largely outside the confidence intervals of the SCD group ( $p<0.05$, figure 1). Overall, for exercise and recovery periods, M1 displayed significant deviations from the SCD control group in terms of [PCr] and $\left[\mathrm{P}_{\mathrm{i}}\right]$. Yet, the return to resting $[\mathrm{PCr}]$ and $\left[\mathrm{P}_{\mathrm{i}}\right]$ at the end of the recovery period suggests that this observation result of a transient event. Moreover, the fact that time-courses of [PCr] (figure $2 \mathrm{~A}$ ), $\left[\mathrm{P}_{\mathrm{i}}\right]$ (figure $2 \mathrm{~B}$ ) and intramuscular $\mathrm{pH}$ (figure $2 \mathrm{C}$ ) presented by $\mathrm{M} 1$ during the $\mathrm{HIE}$ were always within the confidence intervals of the control SCD group would indicate that the metabolic abnormalities recorded during the MIE were part of an acute event and not of a chronic state. This hypothesis is further documented by the fact that maximal activity of several enzymes involved in muscle energetics are similar between M1 and the control SCD group (table 1). This result suggested that M1 did not present any baseline muscle disorder.

It has been acknowledged that PCr consumption and resynthesis are largely influenced by oxygen supply [14;15]. Indeed, the lower the oxygen availability, the higher the PCr hydrolysis [14] and the slower the PCr resynthesis [15]. Considering that $P C r+P_{i}$ content is constant during the whole protocol [16], we can assume that $P_{i}$ accumulation and disappearance would be also influenced by oxygen availability. In accordance, a high intramuscular $\mathrm{P}_{\mathrm{i}}$ accumulation has been reported during a period of arterial occlusion in mice [17]. On that basis, the abnormalities on $\left[\mathrm{P}_{\mathrm{i}}\right]$ and $[\mathrm{PCr}]$ time-courses recorded in $\mathrm{M} 1$ during the MIE would illustrate a default in oxygen delivery to active muscles during this protocol in M1. Apart from oxygen supply, intramuscular acidosis had also been identified as an accounting factor for the slower post-exercise $\mathrm{PCr}$ resynthesis [18]. In our case, as illustrated in figure $1 \mathrm{C}$, the extent of intracellular acidosis was comparable in M1 and in the SCD group thereby excluding a larger exercise-induced acidosis as an accounting factor of the slower PCr recovery kinetics. On that basis, one can reasonably infer that the metabolic deviations we observed in M1 resulted from an acute and transitory impairment in oxygen delivery.

The lack of exacerbated intracellular acidosis in M1 during MIE (figure 1C) may appear paradoxical in the context of apparent deficiency in oxygen delivery to active muscles. Indeed, ischemia, if any, should have favored non-oxidative glycolytic processes leading to intracellular acidosis [19]. However, because $\mathrm{PCr}$ hydrolysis is associated with $\mathrm{H}^{+}$ consumption in the intracellular space [20], the faster PCr decrease observed in M1 suggests a greater $\mathrm{H}^{+}$removal by that pathway than in the SCD mice group. In other words, it is not excluded that the expected higher non-oxidative glycolysis-related $\mathrm{H}^{+}$production has been compensated by the greater $\mathrm{H}^{+}$removal due to the faster $\mathrm{PCr}$ hydrolysis, explaining why no difference was recorded concerning $\mathrm{pH}$ despite a potential ischemia in $\mathrm{M} 1$. In the same line, considering PCr resynthesis as a protons source [21], the slower PCr recovery kinetics observed in $\mathrm{M} 1$ (figure $1 \mathrm{~A}$ ) can be considered as a reduced $\mathrm{H}^{+}$source during the recovery period thereby limiting intracellular acidosis, potentially counteracting the direct effects of ischemia. In addition, it is also possible that intracellular $\mathrm{H}^{+}$removal was increased in $\mathrm{M} 1$ mouse. Given that the exercise-induced acidosis was not elevated (particularly as compared 
to the intense exercise, figure $2 \mathrm{C}$ ), it is conceivable that extrusion mechanisms did not operate at their maximal capacity and that $\mathrm{H}^{+}$transporters could cope the increase in $\mathrm{H}^{+}$ production so that protons accumulation is limited. This hypothesis is not meaningless given that it has been demonstrated that, at rest and when exercise intensity is low to moderate, the mechanisms involved in intramuscular $\mathrm{H}^{+}$efflux would not be saturated [22].

While the occurrence of VOC has been rarely documented in skeletal muscle $[3 ; 4 ; 5$; 6], vigorous exercise is known to induce, among other factors, deoxygenation, acidosis, dehydration and hyperthermia. Since all these exercise-induced changes could favor $\mathrm{HbS}$ polymerization and so RBCs sickling [2; 23], it would not be surprising that, during physical activity, skeletal muscle might suffer of VOC. With this in mind, we can reasonably assume that the acute muscular lack of oxygen delivery to exercising muscle we observed in M1 could be suggestive of a VOC. Of interest, we observed the exacerbated metabolic changes throughout the MIE whereas we could have expected to observe these changes during the $\mathrm{HIE}$ which led to a more pronounced acidosis, a potential accounting factor of $\mathrm{HbS}$ polymerization and VOC $[24 ; 25]$. The present results suggest that a VOC can intervene even during moderate intensity exercises in SCD mice. While the fact that the HIE was performed prior to the MIE may have trigger the anomalies observed during the MIE, this possibility could not be verified in our study given that the order between the protocols was randomized in all mice. A more straightforward analysis of the triggering factors of the hypothesized VOC would be of interest.

\section{Conclusion}

To conclude, we have described in the present study, for the first time in a sickle cell mouse in vivo, exacerbated metabolic changes triggered by an exercise session that would be suggestive of a live observation of a muscular VOC. Although of interest, the issue of the potential triggering effect of exercise would have to be further documented, as we did not evidence a direct cause-effect relationship.

\section{Acknowledgments}

This study was supported by Centre National de la Recherche Scientifique (CNRS UMR 7339) and a grant of Société Française de Myologie and Genzyme. This work was performed by a laboratory member of France Life Imaging network (grant ANR-11-INBS-0006). The funders had no role in study design, data collection and analysis, decision to publish, or preparation of the manuscript. 


\section{References}

[1] P.G. Vekilov, Sickle-cell haemoglobin polymerization: is it the primary pathogenic event of sickle-cell anaemia? Br J Haematol 139 (2007) 173-84.

[2] D.C. Rees, T.N. Williams, M.T. Gladwin, Sickle-cell disease. Lancet 376 (2010) 2018-31.

[3] V.C. Ejindu, A.L. Hine, M. Mashayekhi, P.J. Shorvon, R.R. Misra, Musculoskeletal manifestations of sickle cell disease. Radiographics 27 (2007) 1005-21.

[4] H.R. Schumacher, Jr., W.M. Murray, M.K. Dalinka, Acute muscle injury complicating sickle cell crisis. Semin Arthritis Rheum 19 (1990) 243-7.

[5] B. Malekgoudarzi , S. Feffer Myonecrosis in Sickle Cell Anemia. New England Journal of Medicine 340 (1999) 483-483.

[6] P. Vicari, R. Achkar, K.R. Oliveira, et al., Myonecrosis in sickle cell anemia: case report and review of the literature. South Med J 97 (2004) 894-6.

[7] B. Chatel, L.A. Messonnier, C. Hourde, et al., Moderate and intense muscular exercises induce marked intramyocellular metabolic acidosis in sickle cell disease mice. J Appl Physiol (1985) (2017).

[8] B. Giannesini, M. Izquierdo, P.J. Cozzone, D. Bendahan, Metabolic underpinnings of the paradoxical net phosphocreatine resynthesis in contracting rat gastrocnemius muscle. Biochim Biophys Acta 1553 (2002) 223-31.

[9] L.C. Wu, C.W. Sun, T.M. Ryan, et al., Correction of sickle cell disease by homologous recombination in embryonic stem cells. Blood 108 (2006) 1183-8.

[10] Y. Le Fur, F. Nicoli, M. Guye, et al., Grid-free interactive and automated data processing for MR chemical shift imaging data. Magma 23 (2010) 23-30.

[11] Z. Argov, M. Lofberg, D.L. Arnold, Insights into muscle diseases gained by phosphorus magnetic resonance spectroscopy. Muscle \& nerve 23 (2000) 1316-34.

[12] R.B. Moon, J.H. Richards, Determination of intracellular pH by 31P magnetic resonance. J Biol Chem 248 (1973) 7276-8.

[13] O.H. Lowry, J.V. Passonneau, A flexible system of enzymatic analysis, Academic Press, New York,, 1972.

[14] L.J. Haseler, R.S. Richardson, J.S. Videen, M.C. Hogan, Phosphocreatine hydrolysis during submaximal exercise: the effect of FIO2. J Appl Physiol (1985) 85 (1998) 1457-63.

[15] L.J. Haseler, M.C. Hogan, R.S. Richardson, Skeletal muscle phosphocreatine recovery in exercise-trained humans is dependent on O2 availability. J Appl Physiol (1985) 86 (1999) 2013-8.

[16] B. Chance, S. Eleff, J.S. Leigh, Jr., D. Sokolow, A. Sapega, Mitochondrial regulation of phosphocreatine/inorganic phosphate ratios in exercising human muscle: a gated 31P NMR study. Proc Natl Acad Sci U S A 78 (1981) 6714-8.

[17] M. Liu, G.A. Walter, N.C. Pathare, R.E. Forster, K. Vandenborne, A quantitative study of bioenergetics in skeletal muscle lacking carbonic anhydrase III using 31P magnetic resonance spectroscopy. Proc Natl Acad Sci U S A 104 (2007) 371-6.

[18] M. Roussel, D. Bendahan, J.P. Mattei, Y. Le Fur, P.J. Cozzone, 31P magnetic resonance spectroscopy study of phosphocreatine recovery kinetics in skeletal muscle: the issue of intersubject variability. Biochim Biophys Acta 1457 (2000) 18-26.

[19] D.J. Marcinek, M.J. Kushmerick, K.E. Conley, Lactic acidosis in vivo: testing the link between lactate generation and $\mathrm{H}+$ accumulation in ischemic mouse muscle. J Appl Physiol 108 (2010) 1479-86.

[20] B.M. Guthrie, S.P. Frostick, J. Goodman, et al., Endurance-trained and untrained skeletal muscle bioenergetics observed with magnetic resonance spectroscopy. Can J Appl Physiol 21 (1996) 251-63.

[21] G.J. Kemp, C.H. Thompson, A.L. Sanderson, G.K. Radda, pH control in rat skeletal muscle during exercise, recovery from exercise, and acute respiratory acidosis. Magn Reson Med 31 (1994) 103-9.

[22] C. Juel, Regulation of $\mathrm{pH}$ in human skeletal muscle: adaptations to physical activity. Acta Physiol (Oxf) 193 (2008) 17-24.

[23] C. Martin, V. Pialoux, C. Faes, et al., Does physical activity increase or decrease the risk of sickle cell disease complications? Br J Sports Med (2015). 
[24] Y. Ueda, R.M. Bookchin, Effects of carbon dioxide and $\mathrm{pH}$ variations in vitro on blood respiratory functions, red blood cell volume, transmembrane $\mathrm{pH}$ gradients, and sickling in sickle cell anemia. J Lab Clin Med 104 (1984) 146-59.

[25] Y. Ueda, R.L. Nagel, R.M. Bookchin, An increased Bohr effect in sickle cell anemia. Blood 53 (1979) 472-80. 


\section{Figure legends}

Fig. 1. Metabolic variables during the moderate intensity exercise.

Time-courses of $[\mathrm{PCr}](\mathrm{A}),\left[\mathrm{P}_{\mathrm{i}}\right](\mathrm{B})$ and $\mathrm{pH}(\mathrm{C})$ during the rest - stimulation (moderate intensity) - recovery protocol in the SCD group (white circle, mean $\pm S D, n=9$ ) and $M 1$ (black triangle, $n=1$ ). The grey area represents the confidence interval for the SCD group ( $p$ $\leq 0.05$ ).

Fig. 2. Metabolic variables during the high intensity exercise.

Time-courses of $[\mathrm{PCr}](\mathrm{A}),\left[\mathrm{P}_{\mathrm{i}}\right](\mathrm{B})$ and $\mathrm{pH}(\mathrm{C})$ during the rest - stimulation (high intensity) recovery protocol in the SCD group (white circle, mean $\pm S D, n=9$ ) and M1 (black triangle, $n$ $=1)$. The grey area represents the confidence interval for the SCD group $(p \leq 0.05)$. 
Table 1. Muscle enzyme activities

\begin{tabular}{|c|c|c|c|}
\hline & $\begin{array}{l}\text { SCD group } \\
\quad \mathrm{n}=6\end{array}$ & $\begin{array}{c}M 1 \\
n=1\end{array}$ & $\begin{array}{l}\text { Significant } \\
\text { difference }\end{array}$ \\
\hline MK (Ul/mg) & $\begin{array}{c}2.48 \pm 0.40 \\
{[1.56 ; 3.40]}\end{array}$ & 2.85 & NS \\
\hline $\mathrm{CK}(\mathrm{UI} / \mathrm{mg})$ & $\begin{array}{c}16.1 \pm 1.4 \\
{[12.8 ; 19.4]}\end{array}$ & 15.6 & NS \\
\hline HEX (UI/mg) & $\begin{array}{c}0.035 \pm 0.004 \\
{[0.026 ; 0.043]}\end{array}$ & 0.039 & NS \\
\hline ENO (Ul/mg) & $\begin{array}{c}4.03 \pm 0.34 \\
{[3.25 ; 4.81]}\end{array}$ & 380 & NS \\
\hline LDH (Ul/mg) & $\begin{array}{c}5.27 \pm 0.40 \\
{[4.34 ; 6.19]}\end{array}$ & & NS \\
\hline $\mathrm{CS}(\mathrm{UI} / \mathrm{mg})$ & $\begin{array}{c}0.053 \pm 0.003 \\
{[0.046 ; 0.060]}\end{array}$ & 0.055 & NS \\
\hline ENO / CS & $\begin{array}{c}76 \pm 8 \\
{[58 ; 95]}\end{array}$ & 69 & NS \\
\hline
\end{tabular}

Data are presented as mean \pm SD [95 \% confidence interval]. MK: myokinase, CK: creatine kinase, HEX: hexokinase, ENO: enolase, LDH: lactate dehydrogenase, CS: citrate synthase. The value of M1 was always included within the confidence intervals of the SCD group. 


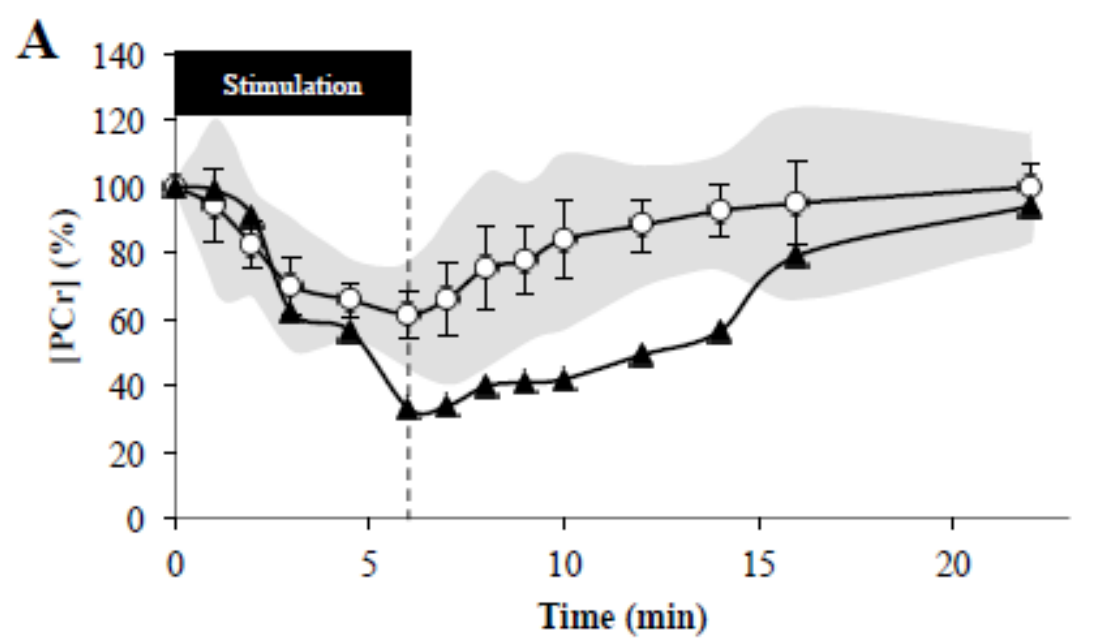

B

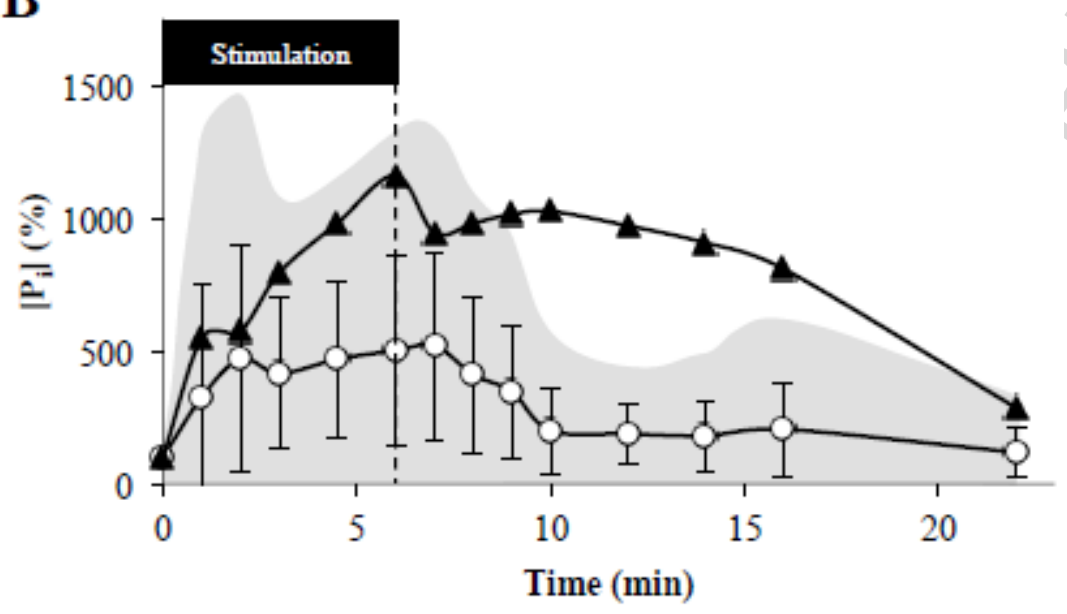

C

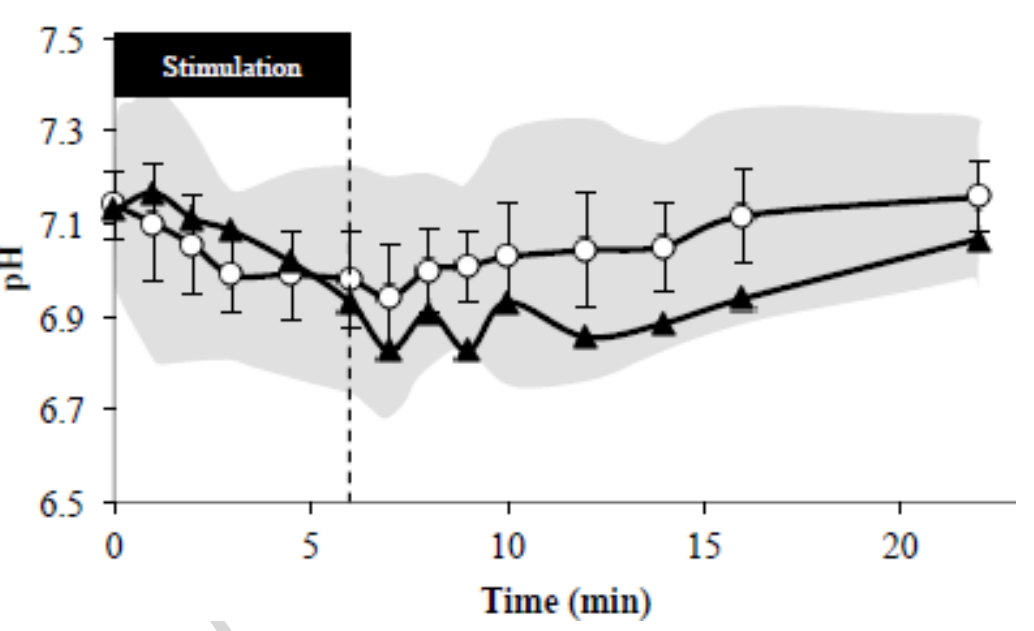

Figure 1 

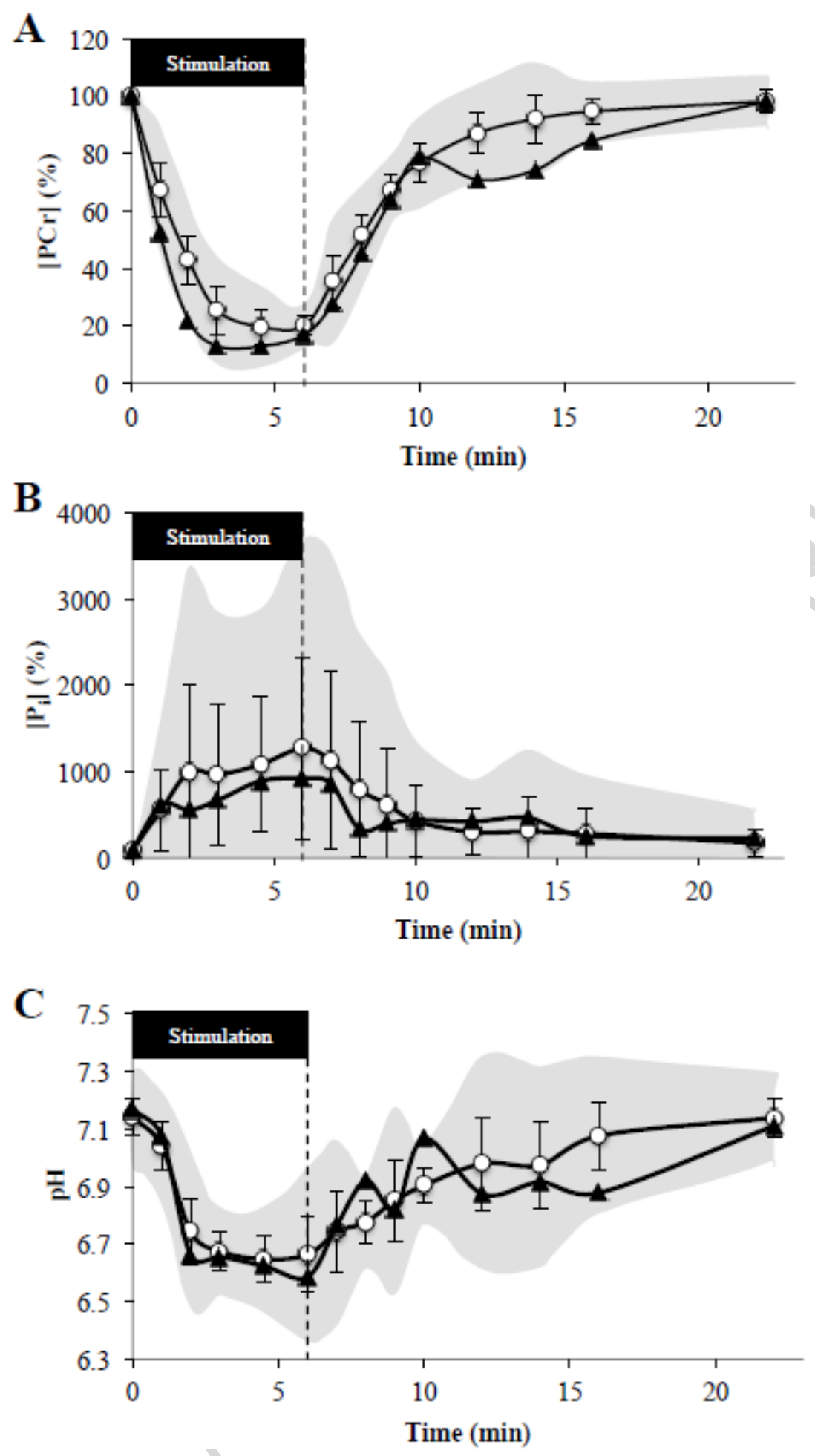

Figure 2 